\title{
Surfaces
}

\section{THE NARRATIVE ACT: WITTGENSTEIN AND NARRATOLOGY}

\section{Henry McDonald}

Volume 4, 1994

URI : https://id.erudit.org/iderudit/1064952ar

DOI : https://doi.org/10.7202/1064952ar

Aller au sommaire du numéro

\section{Éditeur(s)}

Les Presses de l’Université de Montréal

ISSN

1188-2492 (imprimé)

1200-5320 (numérique)

Découvrir la revue

Citer cet article

McDonald, H. (1994). THE NARRATIVE ACT: WITTGENSTEIN AND

NARRATOLOGY. Surfaces, 4. https://doi.org/10.7202/1064952ar
Résumé de l'article

S'inspirant de la seconde phase des écrits de Ludwig Wittgenstein, l'auteur reprend la distinction traditionnelle entre le récit et la narration, ou entre les niveaux diégétique et extra-diégétique du récit, pour en faire une distinction entre le récit et l'acte de narration. Pour décrire les transformations opérées par l'acte de narration, l'auteur élabore ce qu'il appelle le « principe d'incertitude narrative ", selon lequel plus la description d'un récit ou d'une intrigue gagne en précision, plus la description de l'acte de narration qui lui correspond se brouille - et vice versa. L'acte de narration est appréhendé, dans ce cadre conceptuel, comme la différentielle de deux ou plusieurs types de récits (ou intrigues) dans un texte fictionnel donné. La relation entre l'acte de narration, le narrateur, et le contexte culturel est reformulée en conséquence. 


\title{
THE NARRATIVE ACT:
}

\section{WITTGENSTEIN AND NARRATOLOGY}

\author{
Henry McDonald
}

\begin{abstract}
This essay uses the late work of Ludwig Wittgenstein to reformulate the traditional distinction between story and narrative discourse, or diegetic and extra-diegetic levels of narrative, as a distinction between story and narrative act. In describing the transformations performed by the narrative act, the author elaborates the principle of narrative uncertainty, which dictates that the more definite the account of story or plot, the more indefinite the account of the narrative act -- and vice versa. In this conceptual framework, the essay then characterizes the narrative act as the differential, within a given fictional text, of two of more types of stories (or plots), and articulates the relationship between narrative act, narrator, and cultural context.
\end{abstract}

\section{RÉSUMÉ}

S'inspirant de la seconde phase des écrits de Ludwig Wittgenstein, l'auteur reprend la distinction traditionnelle entre le récit et la narration, ou entre les niveaux diégétique et extra-diégétique du récit, pour en faire une distinction entre le récit et l'acte de narration. Pour décrire les transformations opérées par l'acte de narration, l'auteur élabore ce qu'il appelle le $<<$ principe d'incertitude narrative $>>$, selon lequel plus la description d'un récit ou d'une intrigue gagne en précision, plus la description de l'acte de narration qui lui correspond se brouille -- et vice versa. L'acte de narration est appréhendé, dans ce cadre conceptuel, comme 
la différentielle de deux ou plusieurs types de récits (ou intrigues) dans un texte fictionnel donné. La relation entre l'acte de narration, le narrateur, et le contexte culturel est reformulée en conséquence.

The difficulty is to realize the groundlessness of our believing.

-- Wittgenstein, On Certainty

Im Anfang war die Tat. [In the beginning was the deed]

-- Goethe, Faust

Traditionally, the theory of narrative fiction has been directed mainly to the level of the action of the story and its meaning.[1-2] Yet, as more recent narrative theorists have pointed out, it is the narrative presentation of the story which any reader first encounters; the story as a separable part of that presentation is an abstraction constructed after the act.[3] This is not to say that storytellers do not inherit pre-existing cultural materials and indeed narratives out of which they construct their own tales; all tales, as Hawthorne said, are "twice-told," all tellings ultimately retellings.[4] Rather, it is to say that our only access to "the tale itself" is through the act of its being told (or retold); by that act, the story is inevitably rearranged, deformed, and made into a new version that possesses its own singularity -and which may then be retold again. [5]

What this means for interpretation is that the primary object of interpetation is the narrative act of telling the story -- "the story," as Henry James put it, "of the story" [6] -- and that for purposes of criticism, it matters not at all, logically speaking, what the "content" of that story is.[7] For, clearly, failing to tell a story, in the sense of making its events radically ambiguous in meaning and content, is quite as much a narrative act as succeeding in doing so. Moreover, the "failures" in this respect of Henry James, Marcel Proust, and many other modern writers, are instructive. They point up the existence of a principle of narrative uncertainty partly analogous to Heisenberg's Uncertainty Principle in physics.[8]

The latter states that the precision of our measurement of a particle's momentum is inversely proportional to the precision of our measurement of that particle's position. The reason for this is that the measurement of a particle's momentum interferes with and alters the position of that particle -and vice versa. Any tool developed to increase the precision of one value will simultaneously decrease the precision of the other. 
Two common misconceptions about Heisenberg's Uncertainty Principle should be avoided. First, it does not state that "everything is uncertain." On the contrary, it describes an uncertainty that is in fact generated by certainty; inaccuracy about one kind of value is accompanied by accuracy about another kind. In this sense, Heisenberg might reasonably -- if misleadingly -- have termed his formulation the Certainty Principle.

Secondly, the Heisenberg Uncertainty Principle has little to do with the tools which humans have constructed to make measurements; it is independent of any future improvement of their accuracy, or indeed of any new tool that could possibly be constructed. The limitation which it expresses is a limitation not of our tools but of ourselves -- of our "nature." Or rather, to phrase this in the Kantian terms consistent with the Bohr-Heisenberg revolution in modern physics, not of our nature but of the concepts by which we think and act. As Bohr argued, the uncertainties in our measurements of position and momentum (or of other pairs such as energy and time) are related to a basic conflict in the ways we picture matter.[9] As a wave, matter is a temporal phenomenon; as a particle, it is spatial or atemporal. These two pictures are "incommensurate" -- to use Lyotard's term --not in the sense that they contradict one another, but in the sense that they exist on logical levels radically distinct. Yet we apply these conceptions to precisely the "same" empirical phenomenon: matter or energy.

The paradox is akin to that dealt with by Wittgenstein in his discussion of the duck/rabbit drawing of Gestalt psychology, in which the same drawing may appear to the observer sometimes as a duck, sometimes a rabbit, but never both at the same time. [10] Dismissing psychologistic explanations of the phenomenon, Wittgenstein asked: How is it possible for the same drawing to "mean" so differently? Wittgenstein was intrigued by this example because it dramatized on a perceptual level what is more often present to us on an intellectual one: the incommensurate nature of some of the most basic concepts which we apply to reality. We can no more "think" of something as at once a wave and a particle than we can "see" a picture as at once a duck and a rabbit.

And so it is with the concepts which we apply to fictional narratives. Like position and momentum in physics, these concepts, story and narrative act, have the same empirical basis in the text, yet are incommensurate logically. [11] The principle of narrative uncertainty expresses such incommensurability as follows: the more definite our account of story or plot, the more indefinite our account of the narrative act. The narrative act is what constructs or makes, in part, the story, and the more we take that story as finished and whole, assigning to it a fixed and reliable meaning, the more we interfere with and "change the values of" what constitutes the narrative act. What constitutes the narrative act is the process of 
constructing or making the story. In so far as interpretation produces "meaning," it produces that which is radically incommensurate with a process or "action." For meaning, like the position of a particle, must be described in atemporal terms, whereas action, like a wave, must be described temporally (this is an observation about critics' and physicists' conventional uses of these words, not a claim concerning their essences). It follows that any interpretation of the story will interfere, although not necessarily to an equal degree, with and change the values of the narrative act by "freezing" the latter at a certain point. By producing, through our interpretations, a "still shot" of the narrative act, we impose an invariant intention on what is in most cases a variable process.

It is important not to confuse the narrative act, and the narrative "presence" which we associate with that act, with any essential subject, textual or nontextual, narrative or authorial, that acts as an epistemological god to impose meaning on and exert control over the text.[12] The narrative presence has no basis or ground except in the narrative act, and that act cannot carry within itself its own predetermined meanings and effects.[13] Like a performative statement, it requires a context, the cultural context of the reader, to gain meaning. [14] The narrative act is indeed a suspended perfor- mative, or a performative that may be realized in a wide variety of contexts. The important point here, however, is that the ways in which the meaning of an action or event of the story may be understood or realized are radically incommensurate with the ways in which the meaning of the narrative act may be understood

or realized. For while the story presupposes a subject (the teller) the narrative act performs the activity of constituting that subject.

To illustrate this point, let us consider another widely discussed example of Wittgenstein: the status of the statements, "I have pain" and "he has pain."[15] Just as "I have pain" is what Lorna Martens terms expressive and does not designate a "someone" who is in pain -- who is not in question -- so too the narrative act expresses or constitutes a self, and does not designate or refer to such a self.[16] Its meaning is performative. Conversely, just as "he has a pain" is denotative and does indeed designate who is in pain, so too the diegetic or story level of narrative makes reference to "selves" in the form of characters with coherent and stable identities. In sum, the diegetic level of narrative employs a concept of subjectivity; the narrative act delineates one. The narrator is indeed a performative presence dispersed along the temporal axis of the text. We cannot at once "see" this dispersal (the narrative act) and what it has produced (characters with fixed identities). Rather, we must activate a sort of "suspension of belief" in the latter to prevent ourselves from losing the thread of, from failing to keep our concentration on, the movement of the former. 
With some "classical" and popular authors, to lose concentration may not, in fact, have major consequences -- since at the "macroscopic" level of much fiction the narrator is indeed an invariant and therefore unnoticeable presence. But much modern fiction (e.g., Henry James's late fiction) forces on us an "atomic" level of concentration that magnifies the narrator's presence and makes her or his slightest "shifts" displace the entire interpretive frame through which we view the story.

Traditional methods of interpretation thus bear a relation to that suggested by much modern fiction which is similar to the relation between classical and modern physics; the former is a special case of the latter. Which is to say: the effects of narrative uncertainty may be more obvious and consequential for, let us say, the works of Vladimir Nabokov and William Faulkner as opposed to many detective and romance novels, but the principle nonetheless applies in both cases. What we call a story's "meaning" is the product of the narrator's struggle with, her or his shaping and deforming of, the cultural materials she inherited as a member of that culture. Hence to reveal that struggle, to describe the narrative act, we must chip away the layers of "meaning" that may have condensed and frozen upon it. We must allow such layers to disperse and melt, so that "the waters" will "lap up" around us, to borrow one of Henry James's favorite images. Since the days of New Criticism, when it became common to grant to criticism something of a "scientific" status, the narrative act has too often been treated as a sort of "knowledge" and reduced to an atemporal, frozen state. The notion of narrative uncertainty seeks to temporalize and make fluid that state -- to direct attention to the narrative act as culturally performative.

Accepting such fluidity entails "living with" uncertainty, but not, as deconstructionists have often done, absolutizing it in the form of an indeterminacy of meaning intrinisic to the nature of language. Narrative uncertainty, however radical, is not absolute uncertainty. In "Signature Event Context," Derrida describes indeterminacy of meaning as just such an absolute; it is "a certain intrinsic conventionality" that can be summarized under the heading, "arbitrariness of the sign," and regarded as "an essential predicate or law" (Derrida's emphasis).[17] To make indeterminacy a "law" is to transform it cognitively into an element of a larger system of determination -- for example, into the "grid" of binary oppositions which Derrida mentions in the same essay (318). It is to fail to remember that our concepts of uncertainty and certainty belong to similar language games. If they did not, we could not know we were uncertain in the first place and our assertion that "we are uncertain" would be senseless.

One of the difficulties with deconstruction is that it assumes that language works in only or mostly one way, as in the often repeated contention that literary language is something "figural" which has no clear "reference."[18] 
But to view language in such abstract terms is to fail to observe that it is a presupposition of many -- not all -- of our language games that words have extra-linguistic reference. To claim the opposite is simply to deny the ways in which, in particular cases, language works.

The primary import of the narrative uncertainty principle, by contrast, is to get us to focus on just such workings: to encourage us to give up any $a$ priori basis for distinguishing "meaning" from arbitrariness, the cognitive from the performative aspects of language, and instead view human action as constitutive of knowledge, rather than as a kind of knowledge. For it is indeed the act, the deed, which provides what Kant called "the conditions of possibility" for knowledge.

To see this, let us consider briefly the main philosophical source for the concept of the narrator I am suggesting: the late works of Wittgenstein. Wittgenstein once described his philo- sophical method as a way of "making propaganda for one style of thinking as opposed to another."[19] The problem with prior "styles of thinking" is that they assumed meaning could be codified into forms of reason which would account for and even dictate human behavior, including language behavior. At the heart of Wittgenstein's new way of thinking was the opposite assumption: that what words mean is less important than what they do. Fond of the quotation from Goethe's Faust, "Im Anfang war die Tat (In the beginning was the deed), "which he quotes in On Certainty, Wittgenstein conceived of language at its most basic level as forms of human action.[20] These forms, or language games, could not be rationalized or grounded (McDonald 36). On the contrary, it was the uses of language that provided the conditions of possibility of reason (McDonald 35). Breakdowns in reason, including philosophical difficulties, could consequently be attributed to misunderstandings about how language worked. By observing and describing the workings of language, the logic of language use could be "perspicuously" presented or shown and the philosophical difficulties not solved but dissolved (Investigations secs. 109, 133).

What is striking about the role action and deed play in Wittgenstein's late method is that "action" is not conceived ontologically (in a manner associated with Nietzsche), but logically, in a Kantian sense. Kant's transcendental or synthetic a priori logic was developed as a means of revealing "the conditions of possibility" of phenomena and their laws. Such logic is a form of nonlogical necessity, a presuppositional logic, which is supposed to provide a rational foundation for science and morals (McDonald 44-5). Wittgenstein assimilated this presuppositional logic to his notion of language as forms of action. What is presupposed by our uses of language -what constitutes their logic -- are loosely formed structures or channels that provide the tracks along which sense and nonsense run (McDonald 59). Such structures, or "language games" and "forms of life," are to be regarded not as forms imposed on phenomena, but as arising from the social and 
cultural contexts in which such phenomena occur (McDonald 60, 68). There are, that is, no fixed, a priori distinctions between the logical, performative features of language and the cognitive, representational ones. Rather, the distinction, while always there, is always different. The task of the philosopher is to observe, record, and describe those differences. "Everything descriptive of a language game," as Wittgenstein said in On Certainty, "is part of logic" (sec. 56).

Despite the concrete, almost observable character of our patterns of language use, they must not be confused with cognitive content or knowledge as found in (classical) scientific explanations. For Wittgenstein, all explanations are themselves part of a logical or conceptual framework; they are not explanations of that framework. Logic is not a type of explanation; it cannot be stated but only shown (McDonald 60). It is what is revealed through or seen in the workings of language. That is why Wittgenstein declared that we must take off our conceptual blinders and see through language as explanation to the multitudinous ways in which it worked. "Don't think, but look!" he exclaims impatiently at one point in the Philosophical Investigations(sec. 66).

To "not think," however, is not an easy task, for it involves learning, ironically, a "new way of thinking." What this new way of thinking implies, for the study of fictional narrative discourse, is that the primary object of criticism is not "the story," but what is presupposed by any story, the narrator. The narrator may be regarded as a form of action that constitutes the conditions of possibility of the narrative. As Genette's work has made clear, all narratives are in the first person, whatever the point of view of the narra tion,[21] so that the primary "condition of possibility" of any narrative is a persondoing the telling. Even if we often, for psychological or other reasons, ignore the presence of the narrator while reading, that presence is nonetheless a logical presupposition of our reading a narrative in the first place. This is not to reintroduce the notion of an essential self to "explain" the narrative act, but rather to insist that our reception, as readers, of that act entails also the reception of a personal presence associated with it. Our "taking in" of that presence signifies that we have, to one degree or another, "made sense" of the narrative act.

The narrator, however, must be conceived not just as a personal presence but as a form of action that operates at a level radically disproportionate to the action of the story. The narrative act has, indeed, a status independent not just of the content of the telling (story and characters), but of any final meaning of the story. The association of the latter with "the author" is nowadays considered naive; but it is in fact no less naive to associate such meaning with "the narrator." For what we call the narrator is not a fixed entity capable of dictating a determinant meaning but is rather the discourse produced by the act of narrating, a discourse which makes meaning and cannot designate it. Whereas Foucault's "author function" 
separates itself from the text in order to impose coherence on it and bring to a halt "the proliferation of discourse," thereby assigning to "the literary" a non-performative status, the narrator is that proliferation or act performed.

Such an act is at once public and finite. It is "public" because it is a verbal performance of which there is no part that could count as nonverbal or private; a narrator, unlike a character, can neither think nor feel without speaking (there can be no "private languages" in narrative fiction).[22] And it is "finite" because it is bounded, or conceptually delimited, by other actions; the narrator has no reference, psychological or otherwise, apart from the social and cultural forces which constitute her or his textual materials. She cannot transcend her own represented range of reality.

This conception of the narrator implies a method of close reading that differs from traditional methods in two ways. First, it does not isolate and focus on particular passages of the text. For if the narrator is a form of action, we cannot privilege certain parts of the text as "representative" of the whole. Rather, we must observe the metonymic dispersal of the narrative presence along the entire course of the text, "reading closely" not for metaphorically "significant" passages, but rather for the forms and functions which the narrative presence takes on. This entails paying close attention to the various types of free indirect discourse (FID) or narrated monologue (in Dorrit Cohn's terminology)[23] found in most modern fiction. As a doublevoiced technique which simultaneously exhibits the performative presence of the narrator and the psychological content of a character, FID is a crucial critical tool for describing the incommensurate elements of many fictional texts.

Secondly, social and historical context must be understood not, in the manner of New Historicists, as something which necessarily subverts narrative or authorial intention. For this understanding posits an opposition between inner/outer, textual/contextual domains that is remarkably similar to that of old historicism. New Historicists, in attributing to narrators an amazingly uniform tendency to deny their complicity with culture, have imposed what amounts to an a priori requirement of narrative unreliability. The verdict of such unreliability encourages New Historicists to look outside for what is covered up within. And what they find, although not reducible to the individual subject, is reassuringly determinate, to be described cognitively in terms of power, ideology, hegemony, and so forth. New Historicists, in sum, have continued to be "bewitched," as Wittgenstein put it, by the metaphysical picture of language as an "inner" phenomenon set in contrast to "outer" reality and culture. Their skeptical critiques of the subject are complemented by a faith in the explanatory powers of culture and history. 
What I am calling the narrative act, by contrast, may be understood as the differential, within a given fictional text, of two or more types of stories (or plots). The two stories, although radically incommensurate, have an identical basis in the text (they cannot be separated in the way the crime and inquest narratives of detective fiction often are). The first type of story is inherited by the narrator; it is formed of pre-existing social and cultural materials. The second type of story is performatively produced by the narrative act and is therefore the product of the narrator's deformation or rearrangement of the elements of the first plot. The meaning of the second plot is not pre-determined or "caused" by the act of narrating but is rather given meaning by the cultural context in which it is received and understood. What we call cultural context does not explain the narrative act but rather enables us to describe it.[24] The "narrator" is thus not a private, internal subject distinct from the more "external" forces of culture but rather the workings of the discourses of culture. As a performative presence dispersed along the temporal axis of the text, she or he may be pictured as a fold in the social and historical surfaces which constitute our sense of subjectivity -- of the "I."

Wittgenstein's notions of language games and forms of life, similarly, do not assign to "context" an explanatory function. Rather, such notions are tools for a discourse of context in which human behavior can be described and "perspicuously" presented. In narrative discourse, social and cultural forces define or constitute the narrative presence. That presence presupposes, and is not produced by, a social and cultural context, a network of both narrative and nonnarrative actions, in which it is embedded and to which it has relation.

Because all tellings are retellings, all narrators are first readers of the tales they retell. As with the Cashinahua storytellers discussed by Lyotard in The Postmodern Condition, they must first be narratees in order to become narrators whose tellings will generate new narratees. Such is the cultural chain of transmission, into which every teller must insert himself or herself in order to be a teller at all. (And clearly the critic is part of that chain, which is not to say that critic and narrator should be given the same status.) To the extent the narrator takes refuge in an epistemologically neutral meaning, authorial or diegetic, that is situated outside this chain of transmission, she or he cripples the culturally and historically constitutive function of the narrative act. It is only by accepting her or his partiality and limitations as a member of a particular culture shaped by a particular history -- by being a narratee of a prior version of the story she tells - -- that the narrator can assert her presence within the tale she is telling.

In sum, Wittgenstein's view of language as performative rejects any hermeneutics of suspicion that would separate cultural forces from literature and explain the latter by means of the former. Language acts are 
"culture acts"; the former presuppose, and are not explained by, the latter. We must stop trying to give "the language game" of fiction a cognitive basis, for "the language-game is so to say something unpredictable... it is not based on grounds. It is not reasonable (or unreasonable)" (On Certainty sec. 559). What makes the fictional narrative act possible is a willingness to trust and treat as "reliable" the cultural forces that are its textual materials. "I really want to say that a language-game is only possible if one trusts something (I did not say 'can trust something')" (On Certainty sec. 509). As with St. Anselm, trust for Wittgenstein is prior to understanding; one trusts in order to understand, takes up a position within a culture in order to act on it. But this means accepting the radical uncertainty of any ultimate basis or ground for that culture. To the very degree we make or perform a commitment to something, we undermine any universal basis for it.

To accept the notion of narrative uncertainty does not entail discrediting reason, in the manner of skepticism. Rather, it entails limiting, in the manner of Kant, the claims of reason.

The principle of narrative uncertainty, like that in physics, is thus founded on a recognition of human limitation, a recognition of the inevitably situated nature of our actions and the partiality of our perspectives. As readers and critics, it is precisely such self-limitation and cultural embeddedness which we must attune ourselves to if we are to recognize and describe what I have been calling the narrative act.

\section{Henry McDonald \\ Dept. of English \\ University of Oklahoma \\ Norman, Oklahoma}

\section{Surface Page d'Acceuil/Home Page}

[1]This essay has benefitted enormously from the perceptive criticism of Alice Stanton. The comments of Marybeth McMahon, Reed Dasenbrock and of anonymous reviewers for Surfaces have been invaluable. Larry Frank, Robert Nye, and Vinay Dharwadker read a very early draft of the essay and provided constructive criticism that was very helpful.

[2]The "tradition" which I refer to is not, of course, that of structuralist narratology but rather a perspective which dates back to E.M. Forster and views "plot," understood as the causal ordering of a basic sequence of events, as the defining feature of fiction, in Aspects of the Novel (New York: Harcourt, Brace and Co., 1927): 86. Peter Brooks aligns himself with this 
tradition, although with some qualifications. He defines plot as an "intentional structure" which provides "the logic and dynamic of narrative," in Reading for the Plot (New York: Knopf, 1984): 10, 12, 326. Paul Ricoeur similarly defines plot as "the intelligible whole that governs a succession of events in any story," in "Narrative Time," in On Narrative, ed. W.J.T. Mitchell (Chicago: Univ. of Chicago Press, 1981): 167. See also Wayne Booth, The Rhetoric of Fiction (Chicago: Univ. of Chicago Press, 1983): 92, 126; Fredric Jameson, The Political Unconscious: Narrative as a Socially Symbolic Act (Ithaca: Cornell, 1981): 19-20; Hayden White, The Content of the Form: Narrative Discourse and Historical Representation (Baltimore: Johns Hopkins, 1987): 12; Walter Ong, Orality and Literacy: The Technologizing of the Word (London: Methuen, 1982): 142-3, 152; and Mieke Bal, On StoryTelling(Sonoma, CA: Polebridge Press, 1991): 52.

[3]This point has been most effectively made by Meir Sternberg in Expositional Nodes and Temporal Ordering in Fiction(Bloomington: Indiana University Press, 1978): 11.

[4]This seems to me the crucial issue illuminated by Lyotard in his critique of "meta-narratives" and championing of "little narratives." See JeanFrançois Lyotard, Just Gaming, tr. Wlad Godzich (Minneapolis: University of Minnesota Press, 1985): 31-41; The Postmodern Condition: A Report on Knowledge, tr. Geoff Bennington and Brian Massumi (Minneapolis: University of Minnesota Press, 1984): 20-21, 36.; The Postmodern Explained: Correspondence 1982-1985 (Minneapolis: University of Minnesota Press, 1992): 27, 54; Heidegger and "the jews," tr. Andreas Michel and Mark S. Roberts ((Minneapolis: University of Minnesota Press, 1990): 26, 81, 84. See also Bill Readings, Introducing Lyotard(London: Routledge, 1991), an extremely insightful discussion of Lyotard and certainly the best I have encountered; and Geoffrey Bennington's Lyotard: Writing the Event (New York: Columbia University Press, 1988): 112-17.

[5]The concept of the singularity of narrative discourse has been presented by Lyotard and is an important component of the notion of "the narrative act" developed here. See, for example, Readings, 57. Wittgenstein's practice of narrativizing (to use Hayden White's term) human behavior through "the description of language games" presupposes such singularity, a fact all too infrequently recognized by his commentators, including Lyotard in The Differend: Phrases in Dispute, tr. Georges Van Den Abbeele (Minneapolis: University of Minnesota Press, 1988).

[6]Henry James, Literary Criticism: French Writers, Other European Writers, The Prefaces to the New York Edition (New York: The Library of America, 1984): 1309.

[7]Jonathan Culler has presented a characteristically lucid and insightful analysis of the "double logic" of story and narrative discourse in "Story and Discourse in the Analysis of Narrative," in The Pursuit of Signs (Ithaca: Cornell University Press, 1981): 169-88.

[8]Arthur Beiser, Modern Physics: An Introductory Survey (Reading, Mass.: Addison-Wesley Publishing Co., 1968): 59-61; Richard Schlegel, Time and 
the Physical World (New York: Dover Publications, 1961): 163-68; Adolph Baker, Modern Physics and Antiphysics (Reading, Mass.: Addison-Wesley Publishing Co., 1968): 192-211; Fred Alan Wolf, Taking the Quantum Leap (San Francisco: Harper \& Row, 1981): 105-24.

[9]Neils Bohr, Atomic Theory and the Description of Nature (Cambridge: Cambridge University Press, 1934).

[10]Ludwig Wittgenstein, Philosophical Investigations, tr. G.E.M. Anscombe (Oxford: Basil Blackwell, 1972): 196-97; Ray Monk, Ludwig Wittgenstein: The Duty of Genius (New York: The Free Press, 1990): 507-9. Subsequent references to the Investigations appear in the text.

[11]My distinction between story and narrative act is more commonly formulated by narratologists as a distinction between story and narrative discourse. Parallel but by no means identical formulations include E.M. Forster's story and plot, Russian formalists' fabula and sujet, Benveniste's histoire and récit, Gerard Genette's diegetic and extradiegetic levels of narrative discourse, Roland Barthes's proairetic and hermeneutic codes, Lubomir Dolezel's the discourse of the characters and the discourse of the narrator, Jean-Francois Lyotard's "what happened" and "it happens," and so on. My use of the distinction between story and narrative act is conceptually closest to that of Lyotard. However, Genette's account, of unequalled precision, beauty, and usefulness, is in my view one of the great intellectual achievements of narrative theory.

[12]Michel Foucault, "What is an Author?" in Contemporary Literary Criticism, eds. Robert Con Davis and Ronald Schleifer (New York: Longman, 1989): 262-75; Roland Barthes, "The Death of the Author," in Image Music Text (New York: The Noonday Press, 1977): 142-54.

[13]This point is emphasized in my The Normative Basis of Culture: A Philosophical Inquiry (Baton Rouge: Louisiana State University Press, 1986), where I argue that Wittgenstein uses the terms "rule" and "norm" in a sense that does not presume rule or norm predetermines application (356). Subsequent references to this work appear in the text.

[14]A performative is defined as a statement which performs the action that it describes. For example, "I now pronounce you man and wife," refers to the act of marrying at the same time it accomplishes that act. It unites a verbal act (or language game) with an extra-verbal action (or form of life). Yet here we encounter two different connotations of the term, "performative." In the writings of John Searle, Emile Benveniste, and John Austin, a performative is treated as a particular kind of statement, one which requires a coherent extra-verbal context in order to have meaning. Thus, "I now pronounce you man and wife," spoken by an actor on stage, is not a "true" performative because it does not "actually" accomplish the act of marrying. By contrast, in the writings of Jacques Derrida, Shoshana Felman, and Barbara Johnson, the notion of language as performative signifies a general property of language, to wit, the property of being always deferred or suspended in meaning because no context can be regarded as providing a sufficient ground or reference to fix that meaning in a fully determinate and unalterable fashion. 
My own use of the term falls midway between these two. A performative is not a particular kind of statement because all language, to greater or lesser degrees, shows its meaning at the same it states that meaning. In literature, these two levels are often radically incommensurate in the sense that what is shown may be radically different from what is said, depending on the context in which the statement is used. The incommensurability of story and narrative act does not privilege "showing" over "telling" in the manner of the New Critics (to do this would be to ignore the basic thrust of Genette's work). Rather, what the narrator shows is less "the story itself," or any meaning associated with that story, but rather the act of telling the story. Such a formulation is consistent with the arguments of Gerald Else, John Jones, and Timothy Reiss that Aristotle's notion of mimesis (as well as Nietzsche's) connotes simulation or make believe, rather than representation or imitation.

But if the performative does not signify a particular kind of statement, neither does it signify a general property of language. There is nothing in the "nature" of language which dictates that its meaning be always indeterminate. The meaning of "I now pronounce you man and wife" may indeed be determinate in many cases -- may be made relatively stable by being given a fixed context. But here it is not the verbal statement as such which confers on it a discrete meaning, but rather the context in which it is used. And context is always at least potentially variable. A performative statement, that is to say, does not pre-determine, or carry within itself, its meaning; such predetermination assumes that there is an interpretation of a statement, or rule, which may be taken as "correct" in some absolute sense. Such a presumption is especially inappropriate in the case of literature. As Wittgenstein put it in the Philosophical Investigations, "any interpretation still hangs in the air along with what it interprets, and cannot give it support" (sec. 198). No rule can determine its own application; rule and application, like discourse and story, are always potentially, but not necessarily actually, incommensurate.

[15]Ludwig Wittgenstein, The Blue and Brown Books(New York: Harper \& Row, 1958): 48-50, 53-54, 67-9, 74; Philosophical Investigations, secs. 293, 302-3, 403-9, pp. 222-4, et al.

[16]Lorna Martens, "Saying 'I"' in Stanford Literature Review 2 (February 1984): 27-46.

[17]Jacques Derrida, "Signature Event Context," in Margins of Philosophy, tr. Alan Bass (Chicago: Univ. of Chicago Press, 1982): 323-24.

[18]"Any conceivable representation of the relations of words to things, powers, persons, modes of production and exchange, juridical or political systems (or whatever name the presumably non-linguistic may be given) will turn out to be one or another figure of speech," J. Hillis Miller, "The Search for Grounds in Literary Study," in Contemporary Literary Criticism, eds. Robert Con Davis and Ronald Schleifer (New York: Longman, 1989): 575. Similarly, Paul de Man: "Rhetoric radically suspends logic and opens up vertiginous possibilities of referential aberration...I would not hesitate to 
equate the rhetorical, figural potentiality of language with literature itself," in Allegories of Reading (New Haven: Yale Univ. Press, 1979): 10. De Man significantly qualifies this contention in The Resistance to Theory (Minneapolis: University of Minnesota Press, 1986): 11.

[19]Ludwig Wittgenstein, Lectures and Conversations on Aesthetics, Psychology and Religious Belief (Berkeley: Univ. of California Press, 1967): 28.

[20]In the Investigations, Wittgenstein says: "The term 'language game' is meant to bring into prominence the fact that the speaking of language is part of an activity, or of a form of life" (sec. 23) and "Words are also deeds" (sec. 546).

[21]Gerard Genette, Narrative Discourse: An Essay in Method, tr. Jane E. Lewin (Ithaca: Cornell Univ. Press, 1980); Narrative Discourse Revisited, tr. Jane E. Lewin (Ithaca: Cornell Univ. Press, 1988).

[22]Wittgenstein, Investigations, secs. 246-8, 262, 268-9. Another way of putting this is to say that while a "character" is given reference within the fictional universe, a reference that may become the basis of a private language, the narrator has no reference outside the narrative act (her or his reference is ultimately supplied by the cultural context of the reader) and therefore has no "self" that could be distinguished from the discourse recorded in the text.

[23]Dorrit Cohn, Transparent Minds: Narrative Modes for Presenting Consciousness in Fiction (Princeton: Princeton University Press, 1978).

[24]Here as elsewhere I use the the term, "description" (Beschreibung), in Wittgenstein's sense: to connote not a positivistic record of an empirical phenomenon, but rather a narrativized account of a human practice. Such narrativization of human behavior is indeed implicit in Wittgenstein's concept of "language game." 